\title{
Life and the environment
}

\section{BOOK TITLE:}

The story of life and the environment: An African perspective

\section{AUTHORS: \\ Jo van As \\ Johann du Preez \\ Leslie Brown \\ Nico Smit}

\section{ISBN:}

978-1-77007-585-6

\section{PUBLISHER:}

Random House Struik, Cape Town, R290

\section{PUBLISHED:}

2012

\section{REVIEW TITLE:}

Life and the environment

\section{REVIEWER:}

Savel Daniels

\section{AFFILIATION:}

Department of Botany and Zoology, Stellenbosch University, Stellenbosch, South Africa

\section{EMAIL:}

srd@sun.ac.za

\section{POSTAL ADDRESS:}

Department of Botany and Zoology, Stellenbosch University, Private Bag X1, Matieland 7602, South Africa

\section{HOW TO CITE:}

Daniels S. Life and the environment. S Afr J Sci. 2013;109(7/8), Art. \#a0018, 1 page. http://dx.doi.org/10.1590/ sajs.2013/a0018
The Story of Life and the Environment: An African Perspective offers a succinct and refreshing look at the geological, biological and environmental history of the African continent. At the same time, the book focuses on more topical contemporary issues such as climate and anthropomorphic changes that face the continent, its biodiversity and the conservation of its fauna and flora. What sets the book apart from existing publications is that it offers unique and novel insights into the major issues that the African continent currently faces.

The book has 11 chapters and is laid out in a logical manner for the non-specialist; this accessibility makes the book a definitive reference for scholars and naturalists alike. The book has an impressive array of photographs, diagrams and graphs that are well explained and easy to follow and which will delight all enquiring and scientifically minded readers. The Story of Life and the Environment: An African Perspective explores complex issues such as the development of the universe and the formation of planets and offers insights into the principals of evolution and of life on earth, which form the introductions to the chapters on biodiversity, ecology and conservation dealt with later.

The authors incorporate both historical and morphological perspectives on taxonomy and combine these with the most recent results from DNA-based phylogenetic studies for prokaryotic (Archaea and bacteria) all the way through to eukaryotic (fungi, Protista and plants) organisms. In addition, each chapter sets out basic principles and examples of, as well as the latest insights into, how processes operate in their surroundings. The book is an essential guide for anyone who has a keen interest in the environment. Its unique focus on African ecosystems makes the book relevant to both local and international scholars. Students who are new to biology will find this book particularly useful. It comes highly recommended. 